\title{
EFFECT OF MOLYBDENUM ADDITION ON MICROSTRUCTURE AND MECHANICAL PROPERTIES OF PLAIN CARBON STEEL WELD
}

\author{
Kunal Dwivedi, Jyoti Menghani \\ Department of Mechanical Engineering, Sardar Vallabhbhai National Institute \\ of Technology, Surat, India 395007
}

Received 20.12.2016

Accepted 21.12.2016

\begin{abstract}
The present investigation has two main objectives; first is optimization of welding process parameters of submerged arc welding (SAW) using Taguchi philosophy and second is to improve the mechanical properties such as strength and microhardness of weld joint by alloying with varying amounts of molybdenum. For optimization of welding process, parameters Taguchi philosophy have been applied on a mild steel plate (AISI C- 1020) of $10 \mathrm{~mm}$ thickness with $60^{\circ}$ groove angle with arc voltage and welding speed as variables and bead width as output variables. A mathematical relationship between bead width, arc voltage and welding speed has also been found using multiple regression analysis for the present base metal plate geometry. After optimizing welding parameters, molybdenum has been added individually to the welding area in varying percentages. The properties of alloyed and unalloyed weld metal bead are compared. The mechanical characterization of weld has been done in terms of microhardness, tensile strength, whereas microstructural characterization has been performed using optical microscopy, XRD and EDS. The presence of molybdenum resulted in bainite structure in weld bead having a refined grain structure, enhancement in tensile strength and microhardness. The XRD results showed the formation of molybdenum carbides justifying the increase in microhardness value.

Keywords: Taguchi method, submerged arc welding (SAW), grain boundary ferrite $(G B F)$, secondary phase $\{F S(A)\}$, acicular ferrite $(A F)$, granular bainite $(G B)$.
\end{abstract}

\section{Introduction}

These days' steel is being widely used in almost everywhere including ship building, constructing buildings etc. The excessive use of steel is due to its excellent mechanical properties. Submerged arc welding (SAW) is done exclusively for thick plates $(10 \mathrm{~mm} \leq$ thickness). The submerged arc welding finds wide industrial application due to its easy applicability, high current density, excellent bead quality and ability to

"Corresponding author: Jyoti Menghani ,jvmenghani@gmail.com 
deposit a large amount of weld metal using more than one wire at the same time. As submerged arc welding involves a number of process variables such as arc voltage, arc current, welding speed, electrode extension etc. each parameter has its own effect on weld bead quality. Thus, in order to obtain best weld bead quality, all the process variables need to be optimized.

Various researchers have optimized process parameters using Taguchi optimization technique and also performed regression analysis using Minitab software [1-7]. Using ANOVA the relative importance of parameters on bead width has also been found.

Plain carbon steel joint has some limitations like poor corrosion resistance, oxidation at elevated temperatures, incapability of deep hardenability of large structures having martensite structure throughout, decrement of strength beyond $700 \mathrm{MPa}$ with loss of impact strength and ductility. Two approaches have been pursued to improve the toughness of weld metal. One is to use different type of fluxes and other of great interest is to alter weld metal composition either through use of new filler metals or by metal powder addition in weld metal [8]. Various researches [9-12] have been done involving alloying of plain carbon steel using elements like molybdenum, chromium, niobium, silicon, nickel etc. Among the alloying elements molybdenum affects properties of plain carbon steel significantly. Thuvander [13] showed that significant amounts of Mo offered excellent properties of weld metals in low alloyed steels. Also, the addition of Mo can greatly increase the mechanical properties of steel. The presence of Mo modifies the ferrite-carbide microstructure so that lamellar pearlite no longer forms, and is replaced by a divorced eutectoid structure, i.e. divorced pearlite, upper bainite and/or acicular ferrite with carbide. The addition of Mo gradually increases the overall mechanical properties of the steel. Mo increases the hardenability (depth upto which steel can be hardened upon quenching) of steel and also contributes in slowing down the critical quenching speed. Molybdenum increases tensile strength of steel and favors the formation of a fine grain structure. Molybdenum forms carbides readily and thus improves the cutting properties in high-speed steels increasing machinability [14-16].

Hence in present investigation Mo is selected as alloying element in steel welds. Further, attempt is made to study the effect of varying amount of Mo addition on steel weld plate of $150 \mathrm{~mm}$ (length) x $32 \mathrm{~mm}$ (width) x $10 \mathrm{~mm}$ (thickness) with $60^{\circ}$ groove angle. Mechanical characterization is done in terms of microhardness and tensile strength, whereas for microstructural characterization optical microscopy, X-ray diffraction (XRD) analysis and scanning electron microscopy (SEM), energy dispersive X-ray spectroscopy (EDS) have been performed.

\section{Experimental}

The experiments were conducted at SVNIT Workshop with the following set-up. SURARC semiautomatic SAW equipment with a constant voltage, rectifier type power source with a 1200 A capacity was used to join two mild steel plates of size $150 \mathrm{~mm}$ (length) x $32 \mathrm{~mm}$ (width) x $10 \mathrm{~mm}$ (thickness). Copper coated electrodes AWS: SFA/A5.17 EL-8, $3.2 \mathrm{~mm}$ diameter of coil form and agglomerated flux OK Flux 10.71 was used. A single $\mathrm{V}$ with $3.2 \mathrm{~mm}$ root-gap and $2 \mathrm{~mm}$ root-face has been selected to join plates in the flat position, keeping the electrode positive and perpendicular to the plate. Taguchi method has been applied using arc voltage \& welding speed as factors 
with 2 levels for each factor to optimize weld bead width. The values of welding parameters along with their different levels are shown in Table 1. The optimized parameters are shown in Table 2.

The welding arc voltage has direct influence on the shape on bead and external appearance of bead. The travel speed has pronounced effect on weld size and penetration for given combination of current and welding voltage [17].

The voltage principally determines the shape of the weld bead cross section and its external appearance. Increasing the welding voltage with constant current and welding speed produces flatter, wider, less penetrated weld beads and tends to reduce the porosity caused by rust or scale on steel [18].

Welding speed is the linear rate at which an arc is moved along the weld joint. With any combination of welding voltage and welding current, the effect of changing the welding speed confirms to a general pattern. If the welding speed is increased, power or heat input per unit length of weld is decreased and less filler metal is applied per unit length of the weld, resulting in less weld reinforcement. Thus, the weld bead becomes smaller [19]. Bead width almost linearly increases with arc voltage and current and decreases, with welding speed [20].

The quality loss function higher the better quality characteristic has been used and can be expressed as:

$$
M S D=1 / n \sum_{i=1}^{n} 1 / y_{i}^{2}
$$

Where: $y_{i}$ are the observed data (or quality characteristics) at the $i^{\text {th }}$ trial, and $\mathrm{n}$ is the number of trial. Here observed data are weld bead width. With two levels each of arc voltage and welding speed weld bead width is measured in four cases. Each case has been repeated only once, so $n$ becomes 1 for each case. Using equation (1) value of MSD is calculated based on which $\mathrm{S} / \mathrm{N}$ ratio is calculated for each case using equation (2):

$$
\eta=-10 \log _{10}(M S D)
$$

Table 1 Measured weld-bead width.

\begin{tabular}{ccccccc}
\hline $\begin{array}{c}\text { Case } \\
\text { no. }\end{array}$ & $\begin{array}{c}\text { No. of } \\
\text { weld } \\
\text { pass }\end{array}$ & $\begin{array}{c}\text { Voltage } \\
(\mathbf{V})\end{array}$ & $\begin{array}{c}\text { Welding } \\
\text { speed } \\
(\mathbf{m t} / \mathbf{m i n})\end{array}$ & $\begin{array}{c}\text { Bead } \\
\text { width } \\
\text { measured } \\
\mathbf{y}^{\prime}(\mathbf{m m})\end{array}$ & MSD, $\mathbf{y}^{\mathbf{2}}$ & $\begin{array}{c}\text { S/N } \\
\text { (dB) }\end{array}$ \\
\hline 1 & 2 & 30 & 0.25 & 16 & 256 & 24.08 \\
2 & 2 & 30 & 0.40 & 13 & 169 & 22.27 \\
3 & 2 & 32 & 0.25 & 19 & 400 & 25.57 \\
4 & 2 & 32 & 0.40 & 15 & 225 & 23.52 \\
\hline
\end{tabular}


Table 2 Mean S/N ratio for weld bead width.

\begin{tabular}{ccc}
\cline { 2 - 3 } & Level 1 & Level 2 \\
\hline Arc voltage & 23.175 & 24.55 (Optimum) \\
Welding speed & 24.825 (Optimum) & 22.895 \\
\hline
\end{tabular}

Main Effects Plot (data means) for S/N ratios

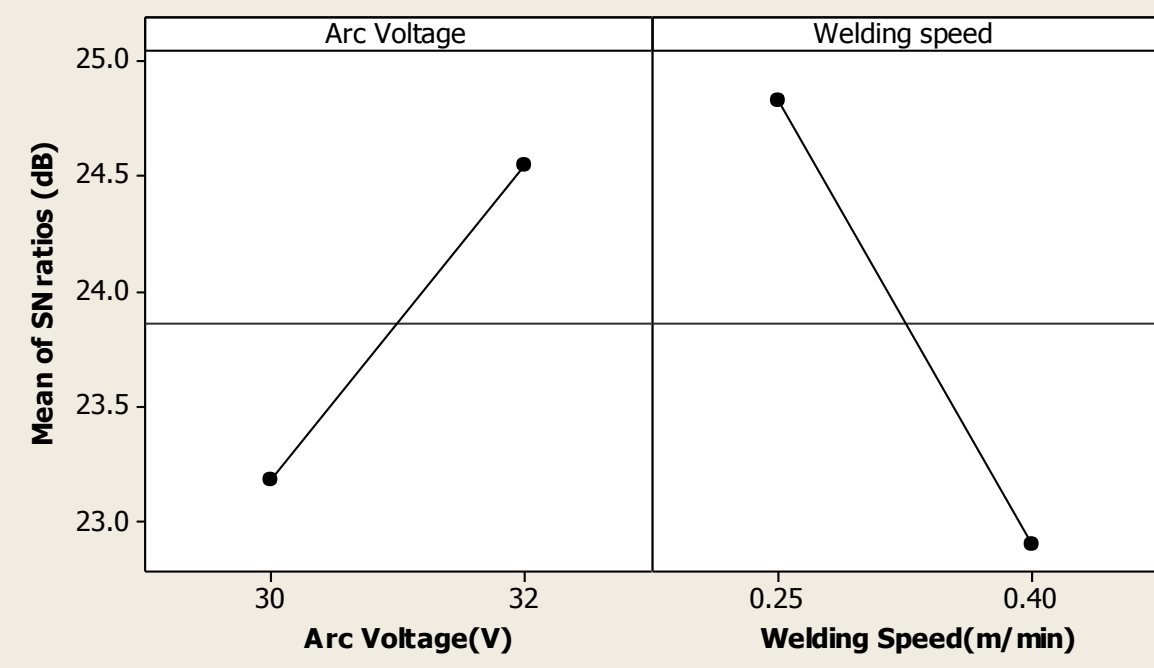

Signal-to-noise: Larger is better

Fig. 1 Graph between voltage, welding speed and mean of $s / n$ ratio

From Fig. 1 it can be observed that $\mathrm{S} / \mathrm{N}$ ratio is related directly to arc voltage and inversely to welding speed. The optimized welding process parameters (arc voltage level $2(32 \mathrm{~V})$ and welding speed level $1(0.25 \mathrm{mt} / \mathrm{min})$ were obtained using Taguchi method. The welding was done using optimized parameters. Further, depending on the quantity of the metal deposited under given experimental conditions per pass the weighed amount of powder (Mo) were inserted in the weld and then welding was done. For comparison of mechanical properties unalloyed weld was also prepared.

Multiple regression analysis has been used to determine the relationship between the dependent variable bead width with the arc voltage and welding speed. The regression analysis has been performed by Minitab 17 software. The regression analysis of the input parameters is expressed in linear equation as follows:

\section{WELD BEAD WIDTH $=-15.42+1.250$ ARC VOLTAGE -23.33 WELDING SPEED}

A test sample, having same size and dimension as per earlier specification has been taken and performed welding at the optimum predicted process parameters at path, welding current, 480 A Arc voltage $32 \mathrm{~V}$, welding speed $250 \mathrm{~mm} / \mathrm{min}$ and electrode stick out $25 \mathrm{~mm}$. Weld bead was measured and it was $16 \mathrm{~mm}$. It is within $95 \%$ confidence level. 
Using MINITAB 17.0 software ANOVA was also performed in order to obtain the relative influence of welding parameters on bead width and the results showed that welding speed affects bead width more than arc voltage. Welding speed contributes to $66.62 \%$ and arc voltage contributes $33.78 \%$ to bead width.

\section{Analysis of Variance}

$\begin{array}{rrrrrr}\text { Source } & \text { DF } & \text { Adj SS } & \text { Adj MS } & \text { F-Value } & \text { P-Value } \\ \text { Regression } & 2 & 18.5000 & 9.2500 & 37.00 & 0.115 \\ \text { ARC } & 1 & 6.2500 & 6.2500 & 25.00 & 0.126 \\ \text { VOLTAGE } & & & & & \\ & 1 & 12.2500 & 12.2500 & 49.00 & 0.090 \\ \text { WELDING } & & & & & \\ \text { SPEED } & & & & & \\ \text { Error } & 1 & 0.2500 & 0.2500 & & \\ \text { Total } & 3 & 18.7500 & & & \end{array}$

After processing all cases with two weld samples for each case, weld joints with $(0.05,0.1,0.15$ and $0.3 \mathrm{wt} . \% \mathrm{Mo})$ and without Mo were subjected to mechanical and microstructural characterization.

For mechanical characterization samples were subjected to tensile testing \& microhardness testing. Tensile tests were performed using universal testing machine (UTM) (Model No: 1/90-1263) at Met Heat Engineers, GIDC-Makapura, (Vadodara), in accordance with ASTM E8M while micro-indentation hardness test were performed as per ASTM E-384:2006 on SHIMADZU HMV 2 series at $9.8 \mathrm{~N}$ indent load.

Microstructural observation and compositional analysis was carried out using scanning electron microscopy (Model No.-Hitachi S3400N) along with EDS facility.XRD was performed in order to determine the main phases in welded steel by using $\mathrm{CuK} \alpha$ radiation. Equipment used for XRD is MINIFLEX.

\section{Results and discussion}

\section{Microstructural results}

All samples prepared for microstructure study were examined under METZER vision plus-5000 optical microscope at 400X with image analyzer SFW scientific. The samples were cleaned, ground, polished and etched with $10 \%$ Nital solution for microstructure study. 


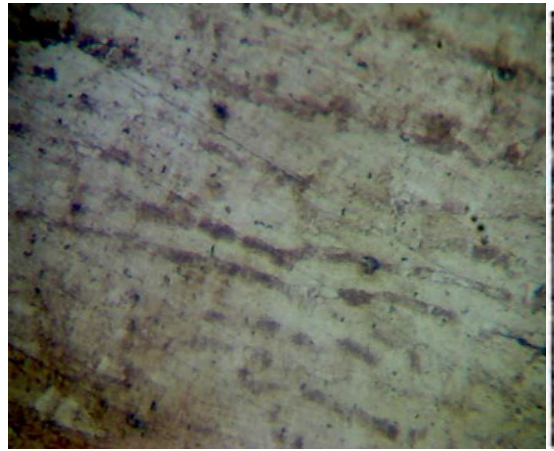

(a) Base metal

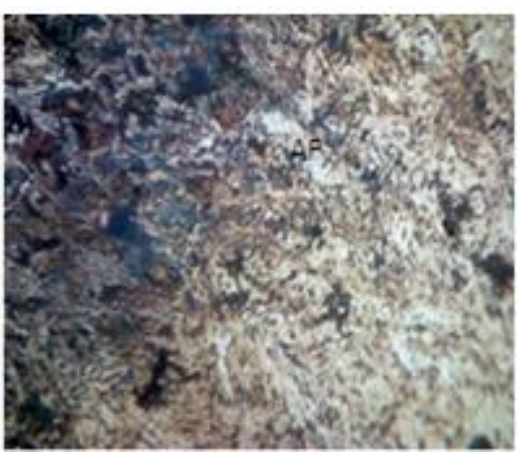

(b) Unalloyed interzone

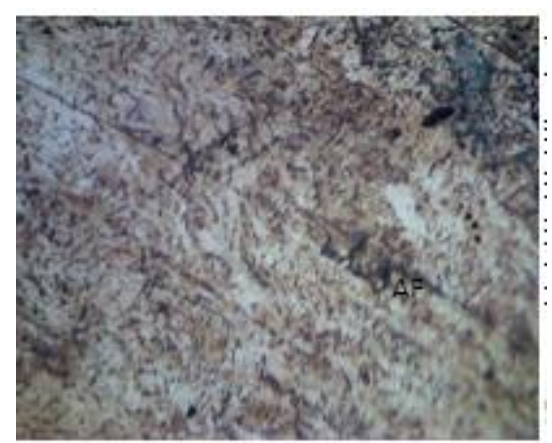

(c) Unalloyed weldzone

Case 2: $0.05 \%$ molybdenum

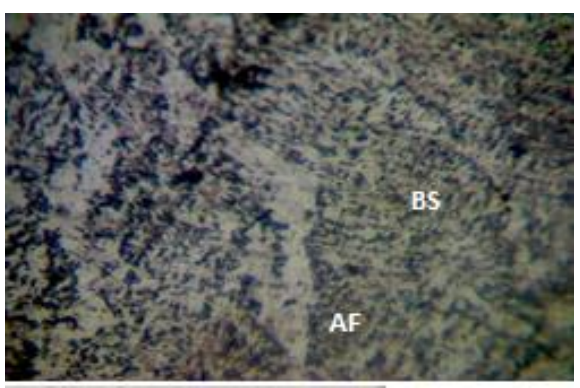

(d) Interzone

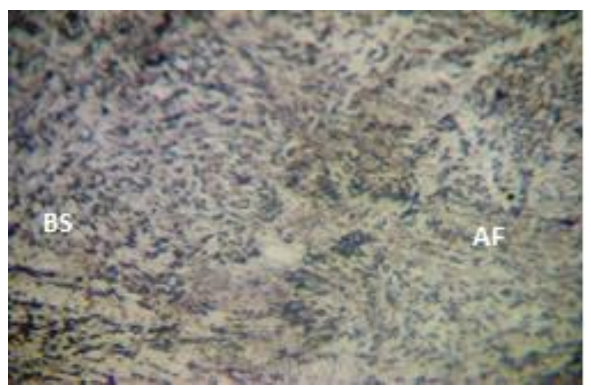

(e) Weldzone 


\section{Case 3: $0.10 \%$ molybdenum}

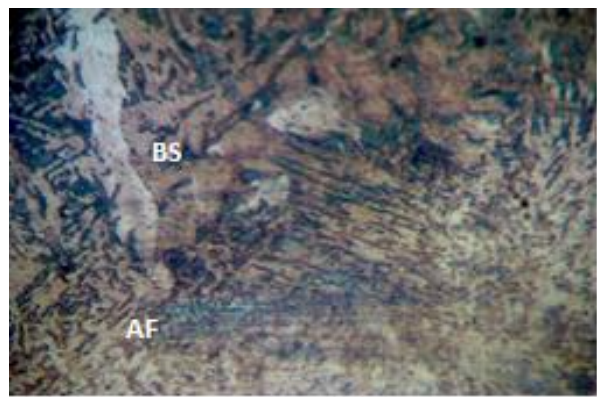

(f) Interzone

\section{Case 4: $0.15 \%$ molybdenum}

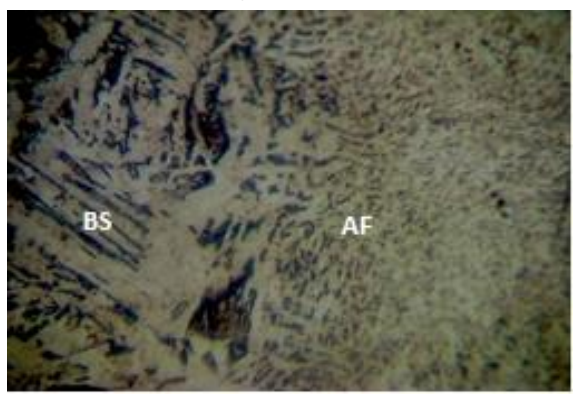

(h) Interzone

Case 5: 0.20 \% molybdenum

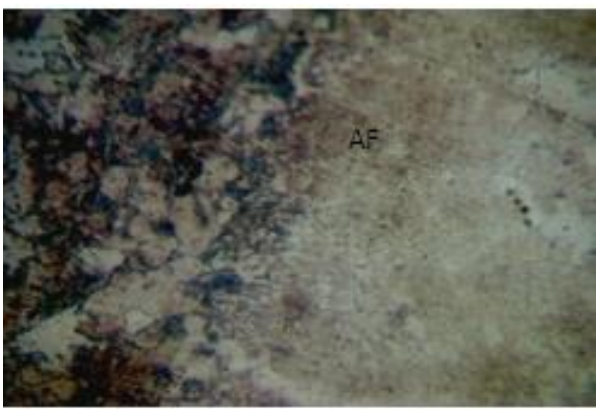

(j) Interzone

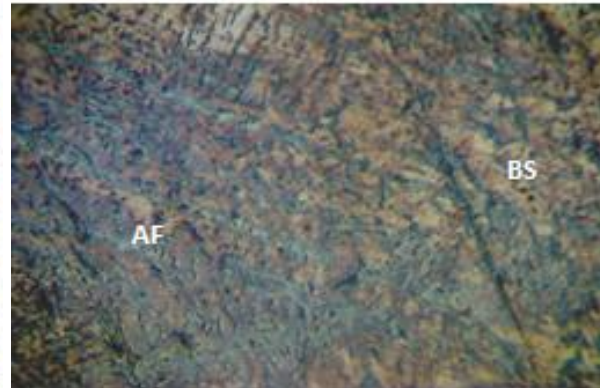

(g) Weldzone

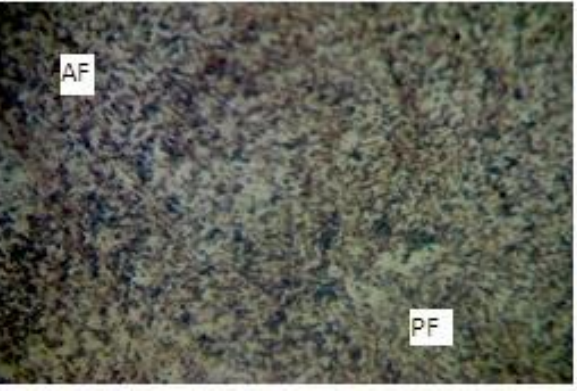

(i) Weldzone

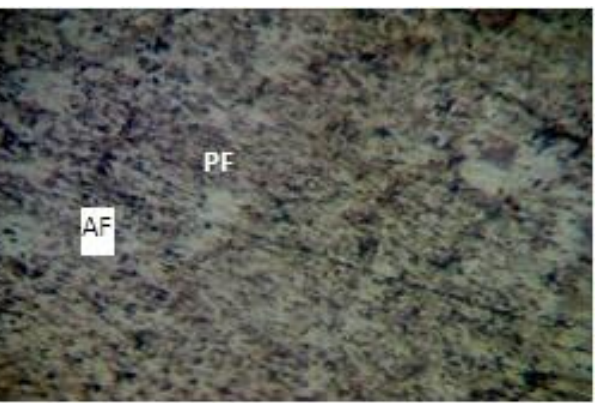

(k) Weldzone

Fig. 2. (a)- (k) Microstructure of base metal, interzone and weldzone in different cases $B S$-bainitic shelves, $P F$ - polygonal ferrite, AF-acicular ferrite)

As shown in the microstructures of weld zone, the addition of molybdenum results in the refinement of grain structure as compared to unalloyed weld metal. As the amount of molybdenum increases grain refinement in weld bead first decreases with molybdenum addition, i.e. $0.05 \%, 0.10 \%, 0.15 \%$ and then increases with $0.20 \%$ Mo. 
The microstructure of the base steel consists of pearlite and ferrite grains. The microstructure of the Mo steel is characterized as bainitic sheaves and some acicular ferrite and the absence of primary grain boundary ferrite. The process of nucleation on inclusions, together with the autocatalytic nucleation, leads to a chaotic arrangement of plates and fine-grained interlocking microstructure characteristic of acicular ferrite. The addition of $\mathrm{Cr}$, Mo and $\mathrm{Mn}$ in quenched and tempered steels suppresses the formation of allotriomorphic ferrites and pearlite, enhancing the formation of martensite and/or bainite. In the present steels, Mo effectively suppresses the formation of grain boundary allotromorphic ferrite and promote the formation of bainite [21].

The feathery structure in microstructure indicates that bainite has been formed (Fig 1-e). The presence of molybdenum shifts the bainite bay to the right which facilitates formation of bainite. Similar results were indicated by [22]. Bhole [8] alloyed weld metal with 0.75 and $0.90 \mathrm{wt} \%$ Mo and found that Mo addition results in the formation of predominant acicular ferrite (AF) and granular bainite (GB), at the expense of ferrite with secondary phase FS(A) and grain boundary ferrite (GBF) in weld metal. However, Yoshino [23] investigated that Mo increases hardenability by suppressing the volume of proeutectoid ferrite and replacing it with acicular ferrite. However, in the present investigation we observed that microstructures contain bainite structures.

As per reference [24] Mo efficiently retards the formation of polygonal ferrite formation and lowers the bainite transformation temperature [21].

\section{Microhardness results}

Table 3 Microhardness results.

\begin{tabular}{|c|c|c|c|c|c|}
\hline Case & $\begin{array}{c}\text { Mo } \\
\text { (wt.\%) }\end{array}$ & $\begin{array}{c}\text { Load } \\
\text { applied }\end{array}$ & $\begin{array}{l}\text { Weld } \\
\text { bead }\end{array}$ & $\begin{array}{c}\text { Heat - } \\
\text { affected } \\
\text { Zone }\end{array}$ & Base metal \\
\hline 1 & Unalloyed & $1000 \mathrm{~g}$ & $\begin{array}{c}187 \\
(\mathrm{HV}-1)\end{array}$ & $\begin{array}{c}171 \\
(\mathrm{HV}-1)\end{array}$ & $\begin{array}{c}209 \\
(\mathrm{HV}-1)\end{array}$ \\
\hline 2 & $0.05 \% \mathrm{Mo}$ & $1000 \mathrm{~g}$ & $\begin{array}{c}199 \\
(\mathrm{HV}-1)\end{array}$ & $\begin{array}{c}158 \\
(\mathrm{HV}-1)\end{array}$ & $\begin{array}{c}209 \\
(\mathrm{HV}-1)\end{array}$ \\
\hline 3 & $0.10 \% \mathrm{Mo}$ & $1000 \mathrm{~g}$ & $\begin{array}{c}234 \\
(\mathrm{HV}-1)\end{array}$ & $\begin{array}{c}183 \\
(\mathrm{HV}-1)\end{array}$ & $\begin{array}{c}209 \\
(\mathrm{HV}-1)\end{array}$ \\
\hline 4 & $0.15 \% \mathrm{Mo}$ & $1000 \mathrm{~g}$ & $\begin{array}{c}250 \\
(\mathrm{HV}-1)\end{array}$ & $\begin{array}{c}171 \\
(\mathrm{HV}-1)\end{array}$ & $\begin{array}{c}209 \\
(\mathrm{HV}-1)\end{array}$ \\
\hline 5 & $0.20 \% \mathrm{Mo}$ & $1000 \mathrm{~g}$ & $\begin{array}{c}262 \\
(\mathrm{HV}-1)\end{array}$ & $\begin{array}{c}183 \\
(\mathrm{HV}-1)\end{array}$ & $\begin{array}{c}209 \\
(\mathrm{HV}-1)\end{array}$ \\
\hline
\end{tabular}


The Mo addition to the weld metal results in a continuous increase in microhardness of the weld bead. This is due to the fact that molybdenum is a strong carbide-forming element, resulting in precipitation of carbides which acts as secondary strengthener phase in the microstructure. The results obtained are in quite agreement with Chen [25] who investigated the effect of molybdenum addition on high performance bridge steel using continuous cooling and found that Vickers hardness increases with the increase of molybdenum content due to transformation strengthening and higher dislocation strengthening. As the percentage of Mo increases a preferred segregation of carbides is observed mostly at grain boundaries (will be discussed in EDS results), which results in continuous increase in microhardness value.

The minimum hardness of the heat affected zone (HAZ) (represents those regions in the close proximity of the weld, where the heat input during welding changes the microstructure without melting the steel) can be related to grain growth in the HAZ which can be explained with the help of thermal cycles. The closer to the fusion boundary, the higher the peak temperature becomes and the longer the material stays at high temperatures [24]. Since the grain growth increases with increasing annealing temperature and time, the grain size in the HAZ increases as the fusion boundary is approached. Moreover, the minimum hardness is more likely due to the spheroidisation of cementite platelets in the pearlite colonies [26].

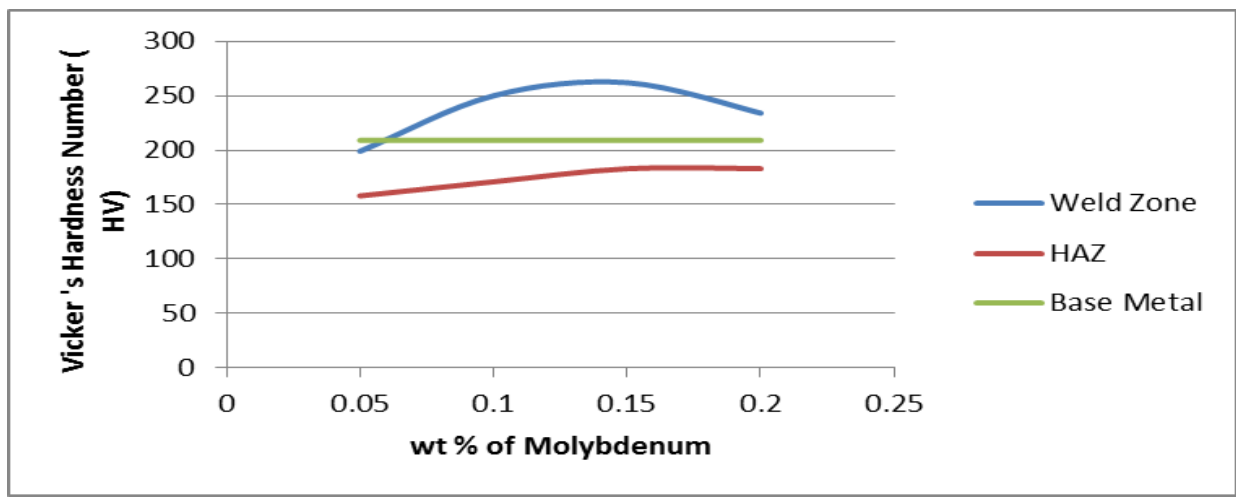

Fig. 3. X-axis:Variation of Vickers's hardness number with wt \% of Mo. Y-axis: Vickers Hardness Number (VPN) 


\section{Tensile test results}

Table 4 Tensile test results.

\begin{tabular}{|c|c|c|c|c|c|c|}
\hline $\begin{array}{c}\text { Mo } \\
(\text { wt. \%) }\end{array}$ & $\begin{array}{c}\text { Dimensions of } \\
\text { specimen } \\
\mathrm{L} \times \mathrm{B} \times \mathrm{H} \\
(\mathrm{mm}) \\
\end{array}$ & $\begin{array}{l}\text { Cross- } \\
\text { section } \\
\text { area } \\
\left(m m^{2}\right)\end{array}$ & $\begin{array}{l}\text { Ultimate } \\
\operatorname{load}(\mathbf{N})\end{array}$ & $\begin{array}{c}\text { Tensile } \\
\text { strength } \\
\text { (MPa) }\end{array}$ & $\begin{array}{l}\text { Failure } \\
\text { location }\end{array}$ & $\begin{array}{c}\text { Nature } \\
\text { of } \\
\text { failure }\end{array}$ \\
\hline Unalloyed & $282 \times 20.90 \times 8.95$ & 187.06 & 94000 & 502.4 & Weld & Ductile \\
\hline $0.05 \%$ Mo & $282 \times 20.90 \times 8.50$ & 177.65 & 99500 & 560.0 & HAZ & Ductile \\
\hline $0.10 \% \mathrm{Mo}$ & $282 \times 20.90 \times 8.96$ & 187.26 & 99000 & 528.6 & $\mathrm{HAZ}$ & Ductile \\
\hline $0.15 \% \mathrm{Mo}$ & $282 \times 20.80 \times 8.77$ & 182.42 & 92500 & 507.1 & HAZ & Ductile \\
\hline $0.20 \%$ Mo & $282 \times 20.00 \times 8.66$ & 173.20 & 91000 & 525.4 & HAZ & Ductile \\
\hline
\end{tabular}

By adding Mo fracture occurs in HAZ indicating the weld zone has higher strength then HAZ. The reason behind all fractures occurring in HAZ is hydrogen cracking. Hydrogen cracking occurs when hydrogen (from moisture in flux), high tensile residual stress \& a crack susceptible microstructure coexists. As the microstructure obtained in above cases shows the presence of coarse grain structure in $\mathrm{HAZ}$, this coarse structure raises residual stresses which make HAZ more susceptible to hydrogen cracking [19].

HAZ toughness is related to HAZ microstructure and this is a function of steel chemical composition and weld thermal cycle. In particular, it is known that low HAZ toughness is associated with coarse grained microstructures which consist of Widmanstätten side plates or upper bainite. In these microstructures, the Widmanstätten or bainitic ferrite grains are separated by low angle boundaries and thus the 'effective' grain size, or the cleavage fracture facet size, is that of the bainite or side plate colony. Weld metal and HAZ studies have suggested that grain boundary nucleated ferrite has a detrimental effect on toughness. It has been postulated that grain boundary ferrite grains offer a preferred site for initiation and propagation of cleavage and that toughness is lowered with increasing grain boundary ferrite width and increase grain boundary ferrite volume fraction. This behavior may be related to strain concentration effects in the softer pro-eutectoid ferrite phase and the tendency for grain boundary ferrite to exist in continuous bands along the prior austenite grain structure [27]. In present investigation Steel alloyed with Mo consist of bainitic sheaves and some acicular ferrite. 
Similar results were obtained by Bhole [8] in which weld metal was alloyed with 0.75 and $0.90 \mathrm{wt} \%$ molybdenum and it resulted in improvement in tensile strength as compared to unalloyed weld zone. Moreover, the strength of HAZ in all cases is even higher than the strength of weld zone in unalloyed case, which means that molybdenum addition enhances the tensile strength. The reason behind this increase in strength is solid solution strengthening which occurs due to molybdenum addition. From the tensile test results we can observe that tensile strength first decreases and then increase, this is due to the reason that as the percentage of molybdenum increases grain refinement first decreases and then increases as is evident from microstructure.

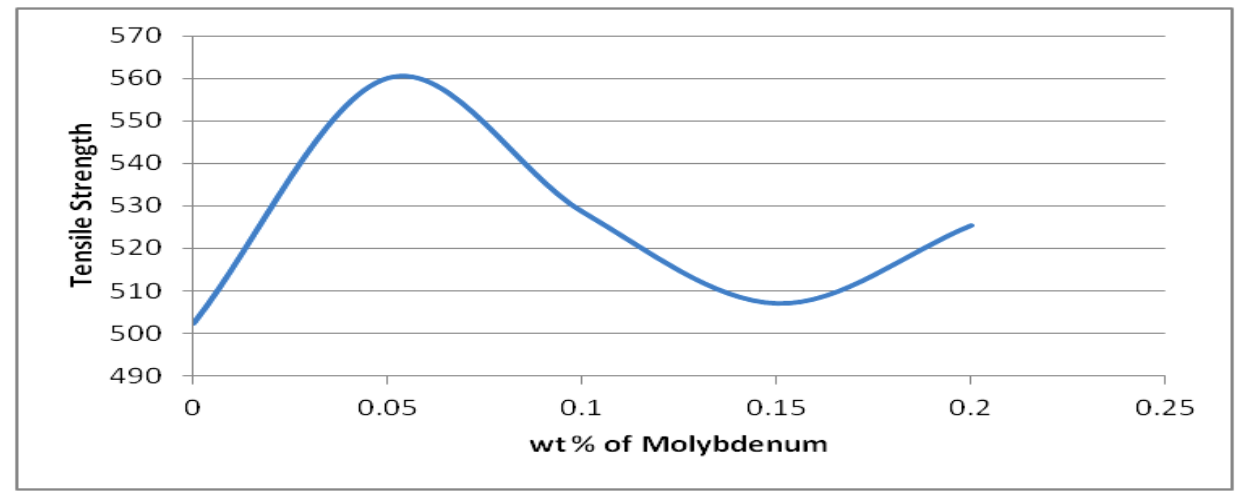

Fig. 4. Variation of tensile strength( $Y$ - axis) with wt.\% of molybdenum(X axis)

\section{EDS Analysis}

Scanning electron microscopy (SEM) associated with EDS was performed in order to investigate the dilution occurred in different zones during welding. Observations were realized with a $15 \mathrm{kV}$ field effect on two samples of molybdenum. The two cases of molybdenum are those showing maximum or minimum microhardness. EDS has been done in order to provide the justification for sudden change in mechanical properties in weld zone and HAZ in terms of dilution. EDS has been performed in terms of spectrum, point analysis. In point analysis 5 points were taken ranging from weld zone to HAZ, then chemical composition was found at those 5 points which gives us the amount of dilution.

\section{Case 2: $0.05 \%$ molybdenum addition (minimum microhardness)}




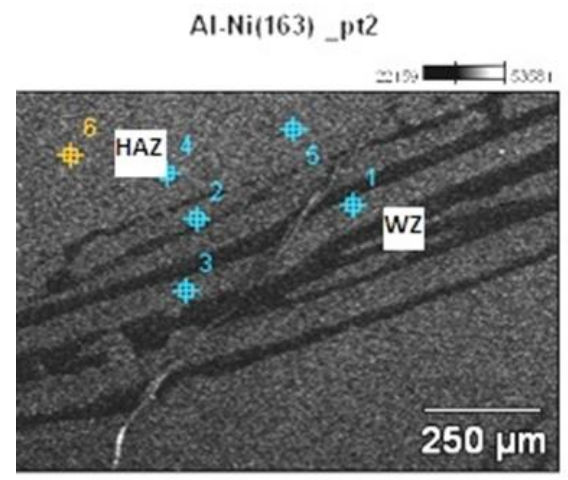

(a)

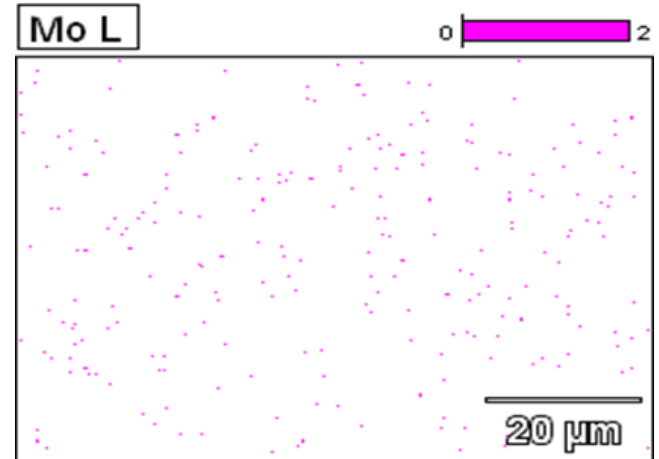

(b)

Fig. 5. a) SEM Points taken from weld zone (WZ) to HAZ on sample. b) EDS Molybdenum distribution in the matrix with $0.05 \% \mathrm{Mo}$.

Table 5. EDS results with $0.05 \%$ molybdenum.

\begin{tabular}{cccrrr}
\hline Elements & Point 1 & Point 2 & Point 3 & Point 4 & Point 5 \\
\hline Fe & 93.6 & 95.52 & 96.89 & 94.69 & 96.12 \\
Mn & 0.6 & 4.48 & 1.07 & 0 & 1.24 \\
Mo & $\mathbf{1 . 7 2}$ & $\mathbf{0}$ & $\mathbf{2 . 2 5}$ & $\mathbf{0 . 3 9}$ & $\mathbf{1 . 0 3}$ \\
P & 0.66 & 0 & 0.24 & 0 & 0 \\
Co & 3.42 & - & 0 & 4.92 & 1.61 \\
\hline
\end{tabular}

Case 5: $0.20 \%$ molybdenum addition (maximum microhardness)

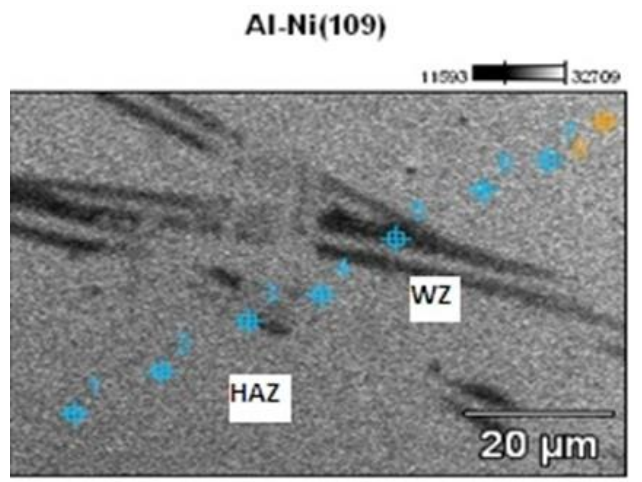

(a)

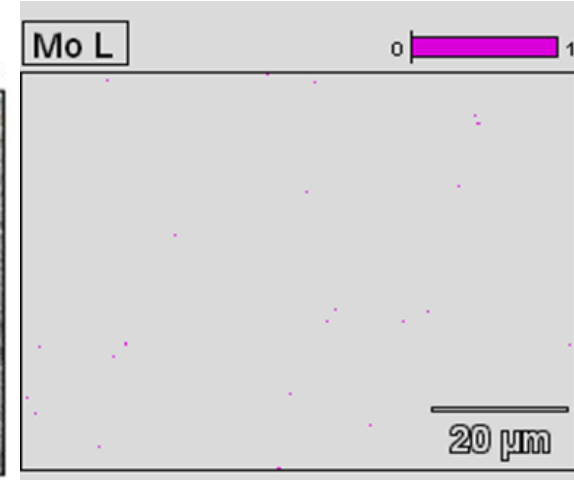

(b)

Fig. 6. a) SEM Points taken from weld zone (WZ) to HAZ on sample, b) EDS Molybdenum distribution in the matrix with $0.20 \% \mathrm{Mo}$. 
Table 6. EDS results with $0.20 \%$ molybdenum.

\begin{tabular}{crrrrr}
\hline Elements & Point 1 & Point 2 & Point 3 & Point 4 & Point 5 \\
\hline Fe & 94.81 & 93.81 & 91.94 & 94.69 & 92.43 \\
Mn & 0 & 1.28 & 0.87 & 0.3 & 2.07 \\
Mo & $\mathbf{2 . 9 1}$ & $\mathbf{2 . 2 1}$ & $\mathbf{4 . 4 6}$ & $\mathbf{2 . 6 2}$ & $\mathbf{3 . 8 3}$ \\
Co & 2.28 & 2.7 & 2.73 & 2.39 & 1.67 \\
\hline
\end{tabular}

From the EDS results it can be observed that the amount of dilution of molybdenum decreases from weld zone to HAZ in both cases, which results in the decrease in microhardness from weld zone to HAZ.

The amount of dilution at 5 points taken is less at each point in $0.05 \%$ molybdenum as compared to $0.20 \%$ molybdenum, which justifies the decrease in microhardness from $0.05 \%$ to $0.20 \%$ molybdenum. From Figure 5 (b) and 6(b) it can be observed that amount of molybdenum in the matrix is evenly distributed which results in better mechanical properties of weld bead. The amount of molybdenum distributed is more case of $0.20 \%$ molybdenum as compared to $0.05 \%$ Mo which justifies our experimental procedure. Moreover, in Figure 6b) as molybdenum is segregated as carbides in certain regions which are nothing but grain boundaries resulting in higher microhardness with $0.20 \%$ molybdenum addition.

\section{XRD results}

XRD was performed in all five cases in order to justify mechanical characterization with microstructural characterization.

The flux used for welding plain carbon steel with SAW had composition of $\mathrm{Al}_{2} \mathrm{O}_{3}, \mathrm{SiO}, \mathrm{Fe}_{2} \mathrm{O}_{3}, \mathrm{~K}_{2} \mathrm{O}, \mathrm{Na}_{2} \mathrm{CO}_{3}, \mathrm{CaCO}_{3}, \mathrm{MnO}, \mathrm{MgO}$ and $\mathrm{TiO}_{2}$. XRD analysis indicates that in unalloyed weld metal $\alpha$-ferrite, cementite, $\mathrm{CaFe}_{2} \mathrm{O}_{4}$ and $\mathrm{Fe}_{2} \mathrm{O}_{3}$ are the major phases. On alloying with molybdenum amount of $\mathrm{CaFe}_{2} \mathrm{O}_{4} \& \mathrm{Fe}_{2} \mathrm{O}_{3}$ phases in the matrix become less as the intensities of their peaks are very low, but $\alpha$-ferrite and cementite remain dominant phases with $0.05 \%$ molybdenum addition. The $\mathrm{CaFe}_{2} \mathrm{O}_{4}$ phase/inclusion has formed on reaction of $\mathrm{CaCO}_{3}$ of flux along with Fe. On increasing molybdenum addition to $0.20 \% \alpha$-ferrite becomes almost negligible while cementite also decreases to a very low amount, while other phases such as $\mathrm{MoO}_{3}, \mathrm{Mo}, \mathrm{MoC}$ undergo continuous fluctuation in amount.

As per reference [21] following things may happen in molybdenum rich steels:

1. In molybdenum containing alloy the $\alpha / \gamma$ boundary collects atoms during the transformation and, as a result, experiences an impurity drag.

2. Molybdenum is carbide formers and as such, at low concentrations, go into solid solution in cementite, but will also form solid solutions in ferrite.

3. In case where alloying element concentration reaches a critical level, the cementite will be replaced by another carbide phase. This change in the carbide phase does not necessarily alter the basic pearlitic morphology and consequently alloy pearlites are obtained in which an alloy carbide is associated with ferrite. These pearlites occur only in medium and highly alloyed steels, usually at the highest transformation 
temperatures. At lower transformation temperatures in the same steel, cementitic pearlite may still form because of the inadequate diffusion of the alloying.

However, in present investigation XRD analysis indicate that although molybdenum lowers the activity of carbon in austenite and promotes carbide formation from the thermodynamic point of view, as is evident from - XRD of molybdenum additions. In HAZ, at the growing interface, subsequent redistribution of molybdenum takes place between the ferrite and the cementite, i.e. molybdenum with its substantial solubility in cementite (carbide formers) will diffuse more intensively to cementite. In this way, the composition of cementite can vary over wide limits. The change in composition of cementite, while not affecting the crystal structure, will influence the pearlite interlamellar spacing, the detailed morphology and the tendency to spheroidize as is evident from microhardness results of HAZ [15]. Once the alloying element concentration reaches a critical level, the cementite will be replaced by another carbide phase. Example for this statement is formation of MoC carbide in present study. This change in the carbide phase does not necessarily alter the basic pearlitic morphology. Further TEM analysis is required to comment upon formation of alloy carbide in present investigation.

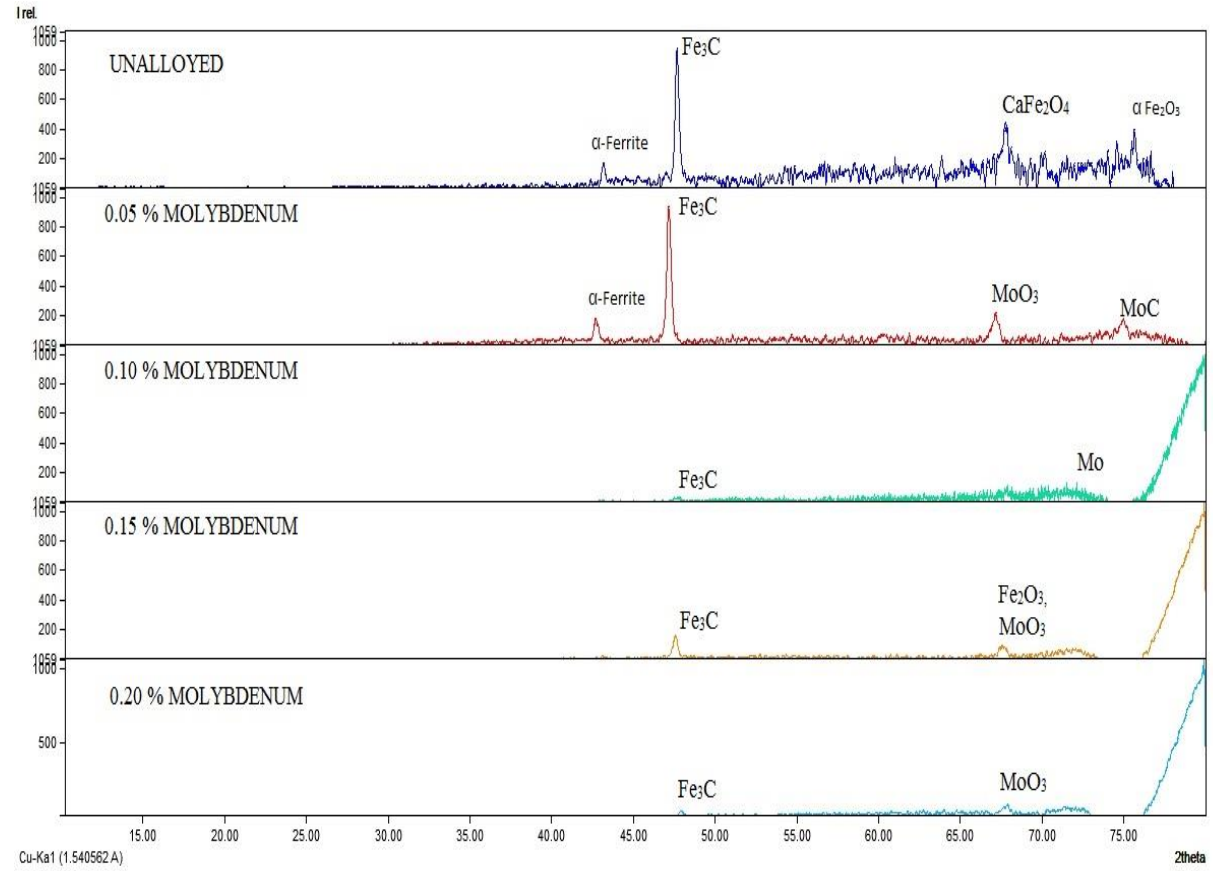

Fig. 7. XRD of different cases 


\section{Conclusions}

1) Based on the present study following conclusions can be drawn:

2) Welding speed has more dominant effect on bead width as compared to arc voltage for the present base metal plate geometry on the basis of regression analysis.

3) Arc voltage and bead width are directly proportional, while welding speed and bead width are inversely proportional.

4) The microstructure, microhardness of the weld zone and HAZ are affected by the varying amount of molybdenum addition.

5) Mo addition results in more refined bainitic microstructure as compared to unalloyed weld metal microstructure.

6) The microhardness of HAZ increases with increasing amount of Mo addition.

7) The dilution of Mo decreases from weld zone to HAZ, resulting in decrease in microhardness from weld zone to HAZ.

8) Mo addition results in higher toughness of weld bead as compared to unalloyed weld bead.

9) Tensile strength first decreases upto $0.15 \%$ Mo addition then increase in 0.20 $\%$ Mo.

\section{References}

[1] L.M Singh, A Saha, Int. Eng. Res. Techn. (IJERT) 1 (2012)1-4.

[2] S. Kumanan, J.E.R. Dhas, K Gowthaman, Indian J. Eng. Mat. Sci. 114 (2007) $177-$ 183.

[3] Y. S. Tarng, W. H. Yang, Mat. Man. Processes 13 (1998) 55-467.

[4] [S. Datta, A. Bandyopadhyay, P. K. Pal, Int. J. Adv. Manuf. Technol. 36 (2008) 1080-1090.

[5] G.K Purohit, Digamber, Int. J. Eng. Res. Development 1 (2012) 9-15.

[6] S. Datta, S.S. Mahapatra, J. Eng. Res. 7 (2010) 42-52.

[7] Y. S. Tarng,W. H. Yang, S. C. Juang, Int. J. Adv. Man. Techn. 16 (2000) 688-694.

[8] S.D. Bhole, J.B. Nemade, L. Collins, Cheng Liu, J. Mat. Proc. Techn. 173 (2006) 92-100.

[9] N.D. Pandey, A. Bharti, S.R. Gupta, ibid., 40 (1994) 195-211.

[10] A.Ma. Paniagua-Mercado, V.M. Lopez-Hirata, H.J. Dorantes-Rosalesa, P.E. Diaz, E.D. Valdez, Mat. Charact. 60 (2009) 36-39.

[11] J.Tušeka, M. Subanb, Faculty of Mechanical Engineering,University of Ljubljana, Aškerčeva 6, 1000 Ljubljana, Slovenia institute za varilstvo, Ptujska 19, 1000 Ljubljana, Slovenia.

[12] N. Bailey, Welding Research Supplement to The Welding Journal, August 1991.

[13] M. Thuvander, L. Karisson, B. Munir, Stainless Steel World 16 (2004) 52-57.

[14] www.uom.ac.mu/faculties/foe/mped/students corner/.../steelbklet.pdf

[15] B. Lindsle, H. Rutz Hoeganaes Corporation Cinnaminson, NJ 08077, USA

[16] C.K Gupta, Extractive Metallurgy of Molybdenum page 26 CTC press ISBN No. $08493-4758$.

[17] B.P. Bamankar, S.M. Sawant, Int. J. Adv. Eng. Res. and Studies 3 (2013) 8-10

[18] http://shodhganga.inflibnet.ac.in/bitstream/10603/2065/15/15 chapter\%205.pdf)

[19] http://shodhganga.inflibnet.ac.in/bitstream/10603/2065/15/15_chapter\%205.pdf)

[20] http://nptel.ac.in/courses/112107144/welding/lecture7\&8.htm 
[21] A. Fadel, D.Glišić, N. Radović, Dj. Drobnjak, J. Mater. Sci. Technol. 28 (2012) 1053-1058.

[22] R.W.K. Honeycombe, H.K.D.H. Bhadeshia, 1996, Steels; Microstructure and Properties, Second Edition, Metallurgy and Materials Science Series, Edward Arnold, London, Great Britain

[23] Y.Yoshino, R.D. Stout, Welding Research, Supplement to The Welding Journal, March,1979, Sponsored By The American Welding Society And The Welding Research Council.

[24] Asi Suikkanen Development and Processing of Low Carbon Bainaitic Steels, Academic dissertation, Faculty of Technology of the University of Oulu, Raahensali, p. 52]

[25] J. Chen, S. Tang, Z. Liu, G.Wang, Mat. Design 49 (2013) 465-470.

[26] S. Kou, Welding Metallurgy,Second Edition,John Wiley \& Sons, Inc., Hoboken, 2003, New Jersey.

[27] The effect of alloying elements on HAZ, Microstructure and Toughness British Steel ECSC Agreement Number 7210.KA/816, FINAL TECHNICAL REPORT

[28] bookshop.europa.eu/.../CGNA15834ENC_001.pdf 